\title{
The problems of genetic support of dividing the black kite (Milvus migrans) into subspecies
}

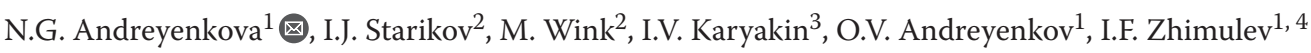 \\ ${ }^{1}$ Institute of Molecular and Cellular Biology, SB RAS, Novosibirsk, Russia \\ ${ }^{2}$ Institute of Pharmacy and Molecular Biotechnology, Heidelberg University, Heidelberg, Germany \\ ${ }^{3}$ Sibecocenter, LLC Novosibirsk, Russia \\ ${ }^{4}$ Novosibirsk State University, Novosibirsk, Russia \\ هe-mail:anata@mcb.nsc.ru
}

\begin{abstract}
The black kite Milvus migrans is a common bird of prey demonstrating remarkable ecological plasticity. It inhabits a variety of habitats and is an increasingly synanthropic species. The black kite is widespread in Eurasia, Africa, Australia and adjacent islands. Palearctic kites migrate to Africa, India and China in winter, but kites of Africa and Australia are partly sedentary and partly seasonal migrants. The wide range and high mobility are the reasons of a complex population structure of the black kite. Commonly five to seven M. migrans subspecies are distinguished, each of which is widespread over extensive areas and has more or less an apparent phenotype. Recently, studies of genetic differences between black kite populations started to emerge. On the grounds of earlier studies of mitochondrial and nuclear genes of this species, we check whether there is a genetic support for separation of the black kite subspecies. Recent studies of some mitochondrial loci substantiate the recognition of at least the European (M. m. migrans), Asian (M. m. lineatus and M. m. govinda), African (M. m. aegyptius and M. m. parasitus), and Australian (M. m. affinis) black kite subspecies. Furthermore, the mitochondrial haplotype difference suggests that the African yellow-billed kite, including M. m. aegyptius and M. m. parasitus, should be a separate species as already proposed, or even two separate species.

Key words: black kite; Milvus migrans; yellow-billed kite; M. m. aegyptius; M. m. parasitus; M. m. migrans; M. m. lineatus; M. m. govinda; M. m. affinis; M. m. formosanus; molecular phylogeny; mitochondrial markers; subspecies.
\end{abstract}

For citation: Andreyenkova N.G., Starikov I.J., Wink M., Karyakin I.V., Andreyenkov O.V., Zhimulev I.F. The problems of genetic support of dividing the black kite (Milvus migrans) into subspecies. Vavilovskii Zhurnal Genetiki i Selektsii= Vavilov Journal of Genetics and Breeding. 2019;23(2):226-231. DOI 10.18699/VJ19.486

\section{Проблемы генетического обоснования выделения подвидов черного коршуна (Milvus migrans)}

\author{
Н.Г. Андреенкова ${ }^{1} \otimes$, И.Ю. Стариков ${ }^{2}$, М. Винк ${ }^{2}$, И.В. Карякин ${ }^{3}$, О.В. АнАреенков ${ }^{1}$, И.Ф. Жимукев ${ }^{1,4}$ \\ ${ }^{1}$ Институт молекулярной и клеточной биологии Сибирского отделения Российской академии наук, Новосибирск, Россия \\ 2 Гейдельбергский университет, Германия \\ ${ }^{3} \mathrm{OOO}$ «Сибэкоцентр», Новосибирск, Россия \\ ${ }^{4}$ Новосибирский национальный исследовательский государственный университет, Новосибирск, Россия \\ هe-mail: anata@mcb.nsc.ru
}

\begin{abstract}
Черный коршун Milvus migrans - распространенный пернатый хищник, который обладает исключительной экологической пластичностью, населяет самые разные биотопы и постепенно становится все более синантропным видом. Ареал обитания черного коршуна охватывает Евразию, Африку, Австралию и прилежащие острова. Коршуны Палеарктики мигрируют на зиму в Африку, Индию и Китай, а коршуны, населяющие Африку и Австралию, частью являются оседлыми, а частью - сезонными мигрантами. Огромный ареал и высокая мобильность обусловливают сложную популяционную структуру черного коршуна. Традиционно выделяется от пяти до семи подвидов, каждый из которых населяет достаточно обширную территорию и имеет более или менее выраженные фенотипические отличия. В последние годы начала накапливаться информация о генетических различиях между популяциями черного коршуна, и эти данные не всегда подтверждают традиционные представления о филогении подвидов. В данной статье мы рассмотрим, какая информация о генетических характеристиках подвидов черного коршуна доступна на сегодняшний день.

Ключевые слова: черный коршун; Milvus migrans; желтоклювый коршун; M. m. aegyptius; M. m. parasitus; M. m. migrans; M. m. lineatus; M. m. govinda; M. m. affinis; молекулярная филогения; митохондриальные маркеры; подвиды.
\end{abstract}

\section{Introduction}

The black kite Milvus migrans is a diurnal raptor of the family Accipitridae, inhabiting a wide breeding range including continental Eurasia, Africa, Australia and several islands. This bird of prey shows remarkable ecological plasticity and inhabits a variety of habitats from the forest and forest-steppe zones to dry steppes and semi-deserts, as well as various mountain habitats. The black kite is one of the few raptors that successfully adapt to living next to humans. It intensely populates the neighborhoods of landfills, agricultural and 
livestock complexes and increasingly nests even in large cities. In the 20th century, the black kite along with other raptors suffered from persecution, pesticides, and landscape changes due to human activity. Now these dangers still exist, although at a reduced scale, since poisonous chemicals and hunting are tightly controlled in European countries. Populations of many birds of prey were dangerously reduced in the second half of the 20th century, and they needed protection and restoration measures (examples are the red kite Milvus milvus, the bengal griffon Gyps bengalensis, and the peregrine falcon Falco peregrinus). In contrast, the black kite is quickly and independently restoring its population and rapidly spreading to new habitats, becoming a common synanthropic species.

Commonly from five to seven black kite subspecies are distinguished, each of which is widespread over an extensive range. Recently, I.V. Karyakin analyzed about 800 black kite photographs in several ornithological databases (mostly Raptors of the World in GBIF) and produced a map of subspecies distribution (Karyakin, 2017). The Palearctic is populated by two subspecies: the western part is occupied by the European black kite $M$. m. migrans, and the eastern part, by the black-eared kite M. m. lineatus. The kites belonging to these subspecies differ in phenotype, but their ranges overlap in Western Siberia forming a wide intergradation zone, where birds with various intermediate phenotypes occur (see the Figure). $M$. m. migrans and M. m. lineatus are migratory birds and spend the winter mainly in Africa and the Indian subcontinent (Ferguson-Lees, Christie, 2001). Southern and Equatorial Africa are populated by the yellow-billed kite, which is usually clearly different from the Eurasian subspecies, sometimes considered a separate species (see below) and, in turn, divided into two subspecies M. m. parasitus and M. m. aegyptius. India and the Indo-Chine countries are inhabited by the sedentary pariah kite M. m. govinda, and Australia, together with the adjacent islands are inhabited by the fork-tailed kite $M$. m. affinis, which migrates seasonally within the Australian continent (Marchant, Higgins, 1993). The Indian and Australian subspecies are very similar in their phe-

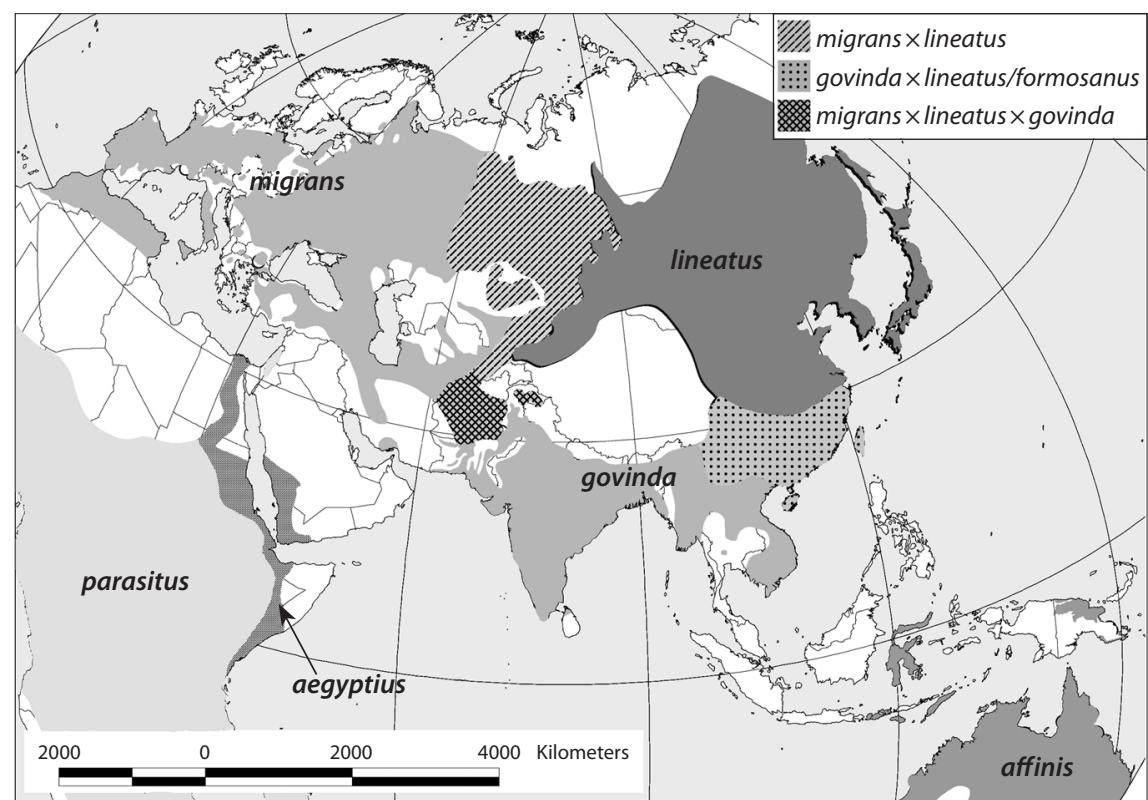

Breeding ranges of the black kite subspecies (Karyakin, 2017).

notypes, but they are considered to be strictly separated by distance. Some researchers recognize a special Taiwan kite $M . m$. formosanus, inhabiting southeastern China (see the Figure).

Other previously proposed races currently are considered as synonyms and are included in the subspecies mentioned above. In 1908, S.A. Buturlin described the subspecies $M$. m. rufiventris from Turkmenistan, later considered as a red morph of M. m. migrans and M. m. ferghanensis from Kyrgyzstan, included in M. m. lineatus (Dement'ev, 1936). Lectotypes and paralectotypes of both races are conserved in the Zoological Museum of Moscow University (Tomkovich, 2001). In 1923, the same author described M. m. tianshanicus from Kyrgyzstan mounts, which was shortly included in $M$. m. lineatus, too. Probably, it resulted from interbreeding of this taxon with nominative subspecies (Dement'ev, 1936). The next two races are currently included in M. m. aegyptius. M. m. tenebrosus was described in 1933 by Grant and Mackworth-Praed. Wintering specimens of this kite collected in 1922 (holotype) at the Ivory Coast and in 1954 in Nigeria are stored at the Natural History Museum (London) (GBIF Secretariat, 2017). M. m. arabicus was described by Swann in 1922, one of specimens of this proposed subspecies was collected in Lahej, Saudi Arabia, in 1899, and now it is stored at the American Museum of Natural History as a holotype (Trombone, 2013), other specimens could be found in several museums. During the examination of yellow-billed kites from Saudi Arabia and Yemen in the Natural History Museum at Tring, England, P.J. Mundy (2011) did not distinguish skins labeled $M . m$. arabicus from M. m. aegyptius; supposedly, the identification is not possible by their morphology. However, the nesting range of this race is situated in a semi-isolated area and the existence of this taxon can be questioned, though we should notify that the information on $M . m$. arabicus is insufficient. Data on genetic features for any of these races are not available; however, they may be of certain interest.

\section{Population genetics of the black kite}

Until now, researchers have been focused on the European black kite population. Usually the black kite is studied together with a close species, the red kite (Milvus milvus), which is a nearly threatened species breeding mainly in Central and Southern Europe. Roques and Negro (2005) hypothesized that the red and black kites diverged as separate species during the last glaciation in the Pleistocene, and now they are isolated reproductively, although the isolation is incomplete (Heneberg et al., 2016). These kites show sympatric speciation, the earlier archaeozoological 
record of Milvus representative are black kite bone remains from Germany dated by $10000 \pm 2000$ years BP, and the remains of both species come from the same European areas since the Neolithic. In that time, coniferous boreal forests, avoided by kites, gave way to temperate-zone forests and agriculture started vigorously, resulting in wood fragmentation (Schreiber et al., 2000). In that early study, allozyme analysis of both species populations from Sachsen-Anhalt in Germany was carried out and these kites were considered very close genetically according to Nei's interspecies distance. However, the black kite is distributed much wider than the red kite and rare hybridization between these species could not apparently result in any significant changes in the black kite gene pool.

Phylogenetic studies on black kites are limited, and only a few researches analyzed relatively representative samples that allowed conclusions to be drawn about the kite population structure. Johnson et al. (2005) analyzed the $C y t B$ and ND2 mitochondrial gene sequences (2146 bp in total) in 43 black and red kite samples from 27 locations, including Western Europe, Africa, South Asia, Japan, Australia, and New Guinea. Mitochondrial control region (547 bp) was also sequenced for 26 samples of the set. The authors managed to construct an informative phylogenetic tree despite a small sample size. That tree demonstrated that $C y t B$ and $N D 2$ haplotypes of the African $M . m$. aegyptius and $M . m$. parasitus differ from the haplotypes of the other $M$. migrans subspecies no less than they differ between the species $M$. migrans and M. milvus. According to the tree, the European M. m. migrans and Australian $M$. m. affinis haplotypes were found to be separate branches of the tree, but the Asian subspecies haplotypes ( $M$. m. lineatus and M. m. govinda) were merged (Johnson et al., 2005).

The purpose of the study (Johnson et al., 2005) was to determine whether the black kites previously inhabiting the Cape Verde Islands were representatives of a particular subspecies. Therefore, almost all the samples used in this work were obtained from old museum collections and were collected mainly in the first half of the 20th century or even earlier. Since then, the black and red kite populations have experienced significant changes due to human activity. Kite populations had been reduced strongly or even disappeared completely from many areas, which was followed by repopulation (Ferguson-Lees, Christie, 2001). Thus, at least some black kite populations passed through a bottle neck and the founder effect, which certainly affected haplotype frequencies. Hence the current haplotype distribution may differ from that obtained by Johnson et al. (2005).

Scheider et al. (2004) used the mitochondrial CytB gene (1143 bp) to construct a phylogeny of black kites. According to this preliminary work, European $M$. m. migrans haplotypes and haplotypes of $M$. m. lineatus from Mongolia formed two separate branches, and the African $M$. m. parasitus was closer to the red kite than to the black kite. In a later research (Scheider et al., 2009) more individuals of M. m. parasitus were added in the analysis and most of them formed a particular clade between M. milvus and others M. migrans.

Heneberg et al. (2016) examined 184 red kite samples and 124 black kite samples from Germany and the Czech Republic. The authors studied phylogeny on the base of mitochondrial $C y t B$ (493 bp) and COl (564 bp) gene fragments. The nuclear $M y c$ (352 bp) gene was also examined, but phylogenetic trees were built for each gene separately. The authors also used sequences available in the GenBank database and concluded that the $C y t B$ gene is best suited for black kite subspecies differentiation, although a relatively small gene fragment was used. Ten closely related $C y t B$ haplotypes were found in $M$. m. migrans samples from Germany and the Czech Republic, including the most common core haplotype. $C y t B$ sequences of another $M$. migrans subspecies from GenBank were included to the phylogenetic tree. $M$. m. lineatus and $M$. m. govinda haplotypes were very close to each other and to $M . m$. migrans haplotypes, but Australian $M$. m. affinis haplotype formed a separate branch of the tree. Even this small $C y t B$ gene fragment shows that the African M. m. parasitus haplotype is different from the other $M$. migrans haplotypes, their genetic distances exceed those between M. migrans and M. milvus (Heneberg et al., 2016).

The same authors (Heneberg et al., 2016) found out that the nuclear $M y c$ gene was not appropriate for discrimination of M. migrans and M. milvus species. All Myc polymorphic sites in the red kite were also polymorphic in the European black kite population. It would be impossible to determine exactly which species a particular Myc sequence belongs to, although the frequencies of $M y c$ alleles in these two species are different. Thus, it cannot be expected that the $M y c$ gene can be used to distinguish black kite subspecies. As nuclear genes have a slow evolution rate, such a result could be expected for young species.

Recently, our group published a small study of $C y t B$ haplotypes in the $M$. $m$. lineatus population from the Tyva Republic (Andreyenkova et al., 2018). We examined 20 independent black kite families and concluded that the most common haplotypes in this population coincided with the minor haplotypes found in the European $M$. m. migrans population by Heneberg et al. (2016). In addition, a $C y t B$ haplotype was discovered in Tuva $M$. m. lineatus, which had been found previously in India and Pakistan $(C y t B-19$ in terms of a study by Heneberg et al., 2016) and been assigned to the Indian M. m. govinda. However, since the same haplotype was found in Japan (Johnson et al., 2005), where M. m. govinda does not live, then the $C y t B-19$ haplotype unlikely belongs to $M$. m. govinda .

\section{Genetic data on individuals of the M. migrans subspecies}

The studies mentioned above (Scheider et al., 2004, 2009; Johnson et al., 2005; Heneberg et al., 2016) demonstrate that some mitochondrial loci allow to distinguish, at least the European (M. m. migrans), Asian (M. m. lineatus and M. m. govinda), African (M. m. aegyptius and $M . m$. parasitus), and Australian (M. m. affinis) black kite subspecies. Below we discuss genetic data for each subspecies in more detail.

Yellow-billed kite, $M . m$. aegyptius and $M$. m. parasitus. It is generally accepted that the yellow-billed kite includes two subspecies (M. m. aegyptius and M. m. parasitus), which breed in Northeastern and Sub-Saharan Africa, respectively (see the Figure). These kites differ from the European M. m. migrans, which are wintering and nesting in Africa. According to all existing data on $C y t B$ gene, the yellow-billed kite differs from all other black kite subspecies no less than the black kite from the red kite, and in most cases the yellow-billed and black kites form even separate clades (Wink, Sauer-Gürth, 2000, 2004; 
Scheider et al., 2004, 2009; Johnson et al., 2005). In a study of West African bird phylogeny based on the COI mitochondrial gene, one $M$. migrans from Nigeria, probably belonging to M. m. parasitus, also formed a clade with M. milvus, and other M. migrans of unclear origin were more distinct (Echi et al., 2015). More comprehensive phylogenetic analysis carried by Minimal Evolution and Neighbor Joining methods with bootstrap support reveals that samples of $M$. m. parasitus from the Ivory Coast and M. m. aegyptius found in Kenya constitute a clade close to all other M. migrans (and also Cape Verde M. milvus fasciicauda); whereas one South African M. m. parasitus gets into the clade with most of M. milvus (Scheider et al., 2009). Nevertheless, position of yellow-billed kites with respect to other taxa is not well supported in that research (values are less than $50 \%$ ), so their exact place in kite phylogeny remains open.

Additionally, $C y t B$ and ND2 genes haplotypes of M. m. parasitus/aegyptius analyzed together were clearly divided into two branches: the first one included seven samples collected in Equatorial Africa and in the south of the Arabian Peninsula, the second one included three samples from South Africa and Madagascar. These two branches were divergent from each other to the same extent as the black kite from the red kite (Johnson et al., 2005). Therefore, the mitochondrial haplotype difference suggests that the yellow-billed kite should be a separate species, as already proposed (Wink, Sauer-Gürth, 2000), or even two separate species.

Taxonomy of $M$. $m$. parasitus/aegyptius is uncertain because the yellow-billed kite is poorly investigated. Young and even adult yellow-billed kites might be sometimes confused with young black kites. In addition, the yellow-billed kite is a seasonal migrant in some areas, and it can occasionally occur outside the breeding range (Clark, Davies, 2018). All these facts lead to misidentification of kites, especially if the birds are caught during migrations. Some sources consider the yellow-billed kite as a separate species Milvus aegyptus and divide it into subspecies $M$. a. aegyptus and M. a. parasitus (Morris, Hawkins, 1998; Sinclair, Langrand, 1998; FergusonLees, Christie, 2005; Gill, Donsker, 2018), but other checklists still interpret $M$. m. parasitus and $M$. m. aegyptius as black kite subspecies (Dickinson, Remsen, 2013; Clements et al., 2018; Orta et al., 2018). In any case, further research is required, including both the study of yellow-billed kite biology and molecular studies involving a large number of samples and additional mitochondrial and nuclear markers.

European black kite, M. m. migrans. This is the best characterized black kite subspecies in terms of both biological features and genetics. Relatively complete information about M. m. migrans seasonal migrations is evaluable (Panuccio et al., 2013; Literák et al., 2017). Various sequences of the mitochondrial $C y t B, N D 2$, and $C O 1$ genes; mitochondrial control region; nuclear $M y c$ gene; and some other European black kite genes are published in the GenBank database. However, two of minor $M$. m. migrans $C y t B$ haplotypes were found as major haplotypes in the nesting $M$. m. lineatus population in Tuva Republic (Andreyenkova et al., 2018), which probably reflect a gene stream from the eastern black kite population to the western one. In any case, analysis of a sufficient sample of other subspecies is required to clarify phylogenetic relationship between $M$. m. migrans and other black kite subspecies.
Black-eared kite, $M$. $\boldsymbol{m}$. lineatus. It has been earlier suggested to consider the black-eared kite as a separate species, M. lineatus (Sibley, Monroe, 1990; Zhukov, 2012; Avibase taxonomic concepts, 2017), but this proposal is inconsistent with population research. As reported by Karyakin (2017), $M$. m. migrans and M. m. lineatus interbreed freely and, apparently, penetrate deeper into the ranges of each other, expanding an intergradation zone. According to Scheider et al. (2004) and Andreyenkova et al. (2018), M. m. migrans and M. m. lineatus $C y t B$ haplotypes form two separate branches of a phylogenetic tree. A $C y t B$ haplotype from Japan (where $M$. m. lineatus breeds) is in the same haplogroup as samples from India and Pakistan (Johnson et al., 2005), where M. m. lineatus, M. m. govinda and, possibly, M. m. migrans breed (Karyakin, 2017). It is therefore unknown which subspecies this haplogroup belongs to. Recently complete mitochondrial genome of a black kite from South Korea was published (Jeon et al., 2018). This territory is included into the $M$. m. lineatus range, although the black kite is a rare species there.

We compared $C y t B$ and ND2 haplotypes from this individual with the haplotypes published by Johnson et al. (2005) and found out that the Korean kite haplotype belongs to the same haplogroup as the samples from Japan, India, and Pakistan. Thus we conclude that this haplotype cannot be assigned to M. m. govinda, as it was done before (Heneberg et al., 2016). It is more likely that all the birds having this haplotype were representatives of $M$. m. lineatus, including individuals from India and Pakistan, especially since they were caught in winter, when $M . m$. lineatus reside in this area. On the other hand, it is still conceivable that $M . m$. lineatus and $M . m$. govinda do not differ in $C y t B$ sequence. There are only two studies using reliable $M$. $m$. lineatus samples from the Tuva Republic (Andreyenkova et al., 2018) and Mongolia (Scheider et al., 2004). Unfortunately, the latter group published only preliminary results and did not submit the $C y t B$ sequences to GenBank. In general, it is only known for now that $M$. m. migrans and $M$. m. lineatus differ in $C y t B$ sequence significantly but to a lesser degree than the species $M$. milvus and M. migrans. It turns out that the most widespread black kite subspecies is very poorly characterized in terms of genetics. Population biology and seasonal migrations of $M$. m. lineatus are also insufficiently understood.

Pariah kite, M. m. govinda. This subspecies is widespread throughout the Indian subcontinent from Pakistan in the west to Indo-China in the east (Karyakin, 2017) and is very poorly investigated, too. M. m. govinda is possibly intergradated with other black kite subspecies in the northwest and northeast of its range; moreover, $M$. $m$. lineatus spends winters in the range of $M . m$. govinda while $M . m$. govinda is considered to be sedentary. Therefore, these subspecies are difficult to distinguish despite the phenotypic differences, and in some cases the validity of subspecies identification is questionable. The only study sequencing mitochondrial genes of kites from India was performed by Johnson et al. (2005). However, all three samples from India used in that study were collected during $M . m$. lineatus wintering period. In addition, as mentioned above, their $C y t B$ and ND2 haplotypes were very close to the haplotype of the sample from Japan (Johnson et al., 2005) and the sample from South Korea (Jeon et al., 2018), so we suggest that all the four samples likely belonged to 
M. m. lineatus. Thereby it can be concluded that no DNA sequences of reliable $M . m$. govinda have been published so far. Phylogenetic relationships of $M$. $m$. govinda with other black kite subspecies remain to be established.

Fork-tailed kite, M. m. affinis. This subspecies is widespread in Australia, New Guinea, and Indonesia. According to current data (Karyakin, 2017) M. m. affinis have no contacts with other black kite subspecies; therefore, significant genetic differences between $M$. m. affinis and other subspecies could be expected, as is the case of the African yellow-billed kite. Unfortunately, very little data on the Australian black kite genetics is available. One Australian sample was used in the study of Scheider et al. (2004); based on $C y t B$ gene the sample was very far from the other black kite subspecies in a phylogenetic tree, both the red and black kites were ingroups. However, the authors themselves considered their result unreliable due to possible DNA degradation. This did not prevent Australian authors from the suggestion that the fork-tailed kite was the ancestor for other subspecies, and Australia was the center of black kite origin (Debus, 2005). These conclusions seem unfounded, since there is not enough information on the Australian black kite genetics. In addition, M. m. affinis looks very similar to Indian $M$. m. govinda. These subspecies are almost indistinguishable in phenotype, reflecting possible close relation. Beside this study, only Johnson et al. (2005) sequenced $C y t B$ and ND2 genes of four M. m. affinis birds: (two from Australia, one from Indonesia, and one from Papua New Guinea). These sequences form a special group but belong to the same branch as the $M$. m. lineatus/govinda haplotypes, indicating a fairly close relationship between the Australian and Asian black kite populations (Johnson et al., 2005).

There are two short (424 and 429 bp) $C y t B$ sequences in Genbank database belonging to black kites (possibly the same bird, no substitutions between the sequences) from India, Andhra Pradesh (HM804897, KC439281, submitted by S. Shivaji, A.P. Reddy, and B.G. Sasikala). It is important that the samples were collected in summer when wintering $M$. $m$. lineatus had left India. We compared these sequences with the known black kite $C y t B$ sequences and found that they clearly belonged to $M$. $m$. affinis haplogroup from the study of Johnson et al. (2005), despite the sequences were rather short. This unexpected finding made us think that Australian black kites were not as isolated as previously thought. Another explanation is that the sequences from India belonged to M. m. govinda and therefore M. m. affinis and M. m. govinda are close in $C y t B$.

Taiwan kite, M. $\boldsymbol{m}$. formosanus. This subspecies belongs to a polytypic group of subspecies together with $M$. m. lineatus and inhabits the eastern part of China, Taiwan and Hainan. The range is located at the junction of $M$. m. govinda and $M$. $m$. lineatus ranges (see the Figure). Some taxonomists do not recognize $M . m$. formosanus as a separate subspecies because its phenotype is intermediate (Karyakin, 2017). It is likely that the range of this subspecies is actually an intergradation zone of $M . m$. govinda and $M$. m. lineatus. We could not find any information on genetics of this subspecies.

\section{Conclusions}

We conclude that the current knowledge of black kite phylogenetics is very far from complete, and genetic research is limited mainly to the European subspecies M. m. migrans. The largest amount of information in the GenBank database is related to the mitochondrial $C y t B$ gene. Comparison of $C y t B$ sequences in different black kite populations indicates that this gene allows the distinction of at least part of the subspecies (Scheider et al., 2004; Johnson et al., 2005; Heneberg et al., 2016; Andreyenkova et al., 2018). As for nuclear markers, data is insufficient: only $M y c$ gene was investigated on a representative sample of red and black kites, but this sequence did not even allow to differentiate these two species (Heneberg et al., 2016).

A collection of black kite samples from the range of all subspecies and intergradation zones between subspecies is required for further study of the black kite. Mitochondrial and nuclear markers (such as microsatellites and SNPs) will clarify black kite population structure features, as well as dispersion history after the end of the Pleistocene glaciation.

\section{References}

Andreyenkova N.G., Andreyenkova O.V., Karyakin I.V., Zhimulev I.F. New haplotypes of the mitochondrial gene $C y t B$ in the nesting population of the Siberian black kite Milvus migrans lineatus Gray, 1831 in the territory of the Republic of Tyva. Doklady Biochemistry and Biophysics. 2018;482(2):242-244. DOI 10.1134/ S1607672918050034.

Avibase taxonomic concepts v. 05 (Jan 2017). Black-eared kite (Milvus lineatus). URL: https://avibase.bsc-eoc.org/species.jsp?lang=RU\& avibaseid $=$ A691B378 on 28.11.2018.

Clark B., Davies R. African Raptors. Bloomsbury Publishing Plc, 2018. Clements J.F., Schulenberg T.S., Iliff M.J., Roberson D., Fredericks T.A., Sullivan B.L., Wood C.L. The eBird/Clements checklist of birds of the world: v2018. Downloaded from http://www.birds. cornell.edu/clementschecklist/download/ on 16.11.2018.

Debus S. The new DNA taxonomy: implications for Australasian raptors and owls. Boobook, J. Australasian raptor assoc. 2005;23(1): 4-5.

Dement'ev G.P. Order Diurnal Raptors Falconiformes or Accipitres: Full Guide of the Birds of USSR. Vol. 3. Moscow; Leningrad: KOIZ Publ., 1936;42-100. (in Russian)

Dickinson E.C., Remsen J.V. (Eds.). The Howard and Moore Complete Checklist of the Birds of the World. 4th Edn. Vol. 1. Non-Passerines. Eastbourne, U.K.: Aves Press, 2013. (Downloadable checklist). Accessed from https://www.howardandmoore.org on 16.11.2018.

Echi P.C., Suresh K.U., George S., Ratheesh R.V., Ezeonu I.M., Ejere V.C., Eyo J.E., Nwani C.D. Molecular resolution of some West African birds using DNA barcoding. Environ. Conserv. J. 2015;16: 87-92.

Ferguson-Lees J., Christie D.A. Raptors of the World. Helm Identification Guides. London, UK: Christopher Helm, 2001.

Ferguson-Lees J., Christie D.A. Raptors of the World: A Field Guide. Princeton: Princeton Univ. Press, 2005.

GBIF Secretariat. 2017. Milvus migrans subsp. tenebrosus C.H.B. Grant \& Praed, 1933. GBIF Backbone Taxonomy. Checklist dataset https:// doi.org/10.15468/39omei accessed via GBIF.org on 22.11.2018.

Gill F., Donsker D. (Eds.). IOC World Bird List (v8.2). 2018. DOI 10.14344/IOC.ML.8.2.

Heneberg P., Dolinay M., Matušík H., Pfeiffer T., Nachtigall W., Bizos J., Šimčíková D., Literák I. Conservation of the red kite Milvus milvus (Aves: Accipitriformes) is not affected by the establishment of a broad hybrid zone with the black kite Milvus migrans migrans in Central Europe. PLoS One. 2016;11(7):e0159202. DOI 10.1371/ journal.pone.0159202.

Jeon H.S., Myeong H., Kang S.G., Kim J.A., Lee S.H., Lee M.Y., An J. The mitochondrial genome of Milvus migrans (Aves, Accipi- 
triformes, Accipitridae), an endangered species from South Korea. Mitochondrial DNA. Pt. B: Resources. 2018;3(2):498-499. DOI 10.1080/23802359.2018.1450678.

Johnson J.A., Watson R.T., Mindell D.P. Prioritizing species conservation: does the Cape Verde kite exist? Proc. Biol. Sci. 2005;272: 1365-1371.

Karyakin I.V. Problem of identification of Eurasian subspecies of the black kite and records of the Pariah kite in Southern Siberia, Russia. Raptors Conservation. 2017;34:49-67. DOI 10.19074/1814-86542017-34-49-67.

Literák I., Horal D., Alivizatos H., Matušík H. Common wintering of black kites (Milvus migrans migrans) in Greece, and new data on their wintering elsewhere in Europe. Slovak Raptor J. 2017;11:91102. DOI 10.1515/srj-2017-0001.

Marchant S., Higgins P.J. Milvus migrans black kite. In: Handbook of Australian, New Zealand \& Antarctic Birds. Vol. 2. Raptors to Lapwings. Melbourne: Oxford Univ. Press, 1993;53-62.

Morris P., Hawkins F. Birds of Madagascar: A Photographic Guide. Yale Univ. Press, 1998.

Mundy P.J. Yellow-billed kites from Arabia. Nat. Univ. of Sci. and Technol., NuSpace Instit. Repository, 2011. Available at http:// ir.nust.ac.zw/xmlui/handle/123456789/562 on 24.11.2018

Orta J., Marks J.S., Garcia E.F.J., Kirwan G.M. Black kite (Milvus migrans). In: del Hoyo J., Elliott A., Sargatal J., Christie D.A., de Juana E. Handbook of the Birds of the World Alive. Barcelona: Lynx Edicions, 2018. Available at https://www.hbw.com/node/52978 on 16.11.2018.

Panuccio M., Agostini N., Mellone U., Bogliani G. Circannual variation in movement patterns of the black kite (Milvus migrans migrans): a review. Ethol. Ecol. Evol. 2013;26(1):1-18. DOI 10.1080/03949370.2013.812147.

Roques S., Negro J.J. MtDNA genetic diversity and population history of a dwindling raptorial bird, the red kite (Milvus milvus). Biol. Conserv. 2005;126:41-50.

Scheider J., Wink M., Stubbe M., Hille S., Wiltschko W. Phylogeographic relationships of the black kite Milvus migrans. In: Chancel- lor R.D., Meyburg B.-U. (Eds.). Raptors Worldwide: Proc. of the VI World Conf. on Birds of Prey and Owls. World Working Group on Birds of Prey. Berlin, Germany, 2004;467-472.

Scheider J., Wink M., Wiltschko W., Stubbe M. Zur Phylogenie und Taxonomie des Schwarzmilan-Subspezies. Populationsökologie Greifvogel- und Eulenarten. 2009;6:233-241.

Schreiber A., Stubbe M., Stubbe A. Red kite (Milvus milvus) and black kite $(M$. migrans): minute genetic interspecies distance of two raptors breeding in a mixed community (Falconiformes: Accipitridae). Biol. J. Linn. Soc. 2000;69:351-365. DOI 10.1111/j.10958312.2000.tb01210.x.

Sibley G.C., Monroe B.L. Distribution and Taxonomy of Birds of the World. New Haven. Yale Univ. Press, 1990.

Sinclair I., Langrand O. Birds of the Indian Ocean islands. Cape Town: Struik Publishers, 1998.

Tomkovich P.S. Order Falconiformes. In: Types of Vertebrates in the Zoological Museum of Moscow University (Archives of the Zoological Museum of Moscow State University. Vol. XLI). Moscow: Moscow Univ. Publ., 2001;100-106.

Trombone T. AMNH Bird Collection. American Museum of Natural History. 2013. Occurrence dataset https://doi.org/10.15468/xvzdcm accessed via GBIF.org on 22.11.2018. https://www.gbif.org/occurrence/858428111 on 28.11.2018.

Wink M., Sauer-Gürth H. Advances in the molecular systematics of African raptors. In: Chancellor R.D., Meyburg B.-U. Raptors at Risk. Berlin: WWGBP, 2000;135-147.

Wink M., Sauer-Gürth H. Phylogenetic relationships in diurnal raptors based on nucleotide sequences of mitochondrial and nuclear marker genes. In: Chancellor R.D., Meyburg B.-U. (Eds.). Raptors Worldwide: Proc. of the VI World Conf. on Birds of Prey and Owls. World Working Group on Birds of Prey. Berlin and MME/BirdLife Hungary, Budapest, 2004;483-498.

Zhukov V.S. Birds of prey in the dynamic environment of the third millennium: status and prospects. In: Proc. VI Int. Conf. on Falconiformes and Owls of Northern Eurasia. Krivoi Rog, Ukraine, 2012; 18-25. (in Russian)

Acknowledgements. This work was supported by State Budgeted Project 0310-2018-0010. The authors gratefully acknowledge the resources provided by the "Molecular and Cellular Biology" core facility of the IMCB SB RAS.

Conflicts of interest. The authors declare no conflict of interest.

Received November 29, 2018. Revised December 11, 2018. Accepted December 11, 2018. 